\title{
Personal finances for long-stay psychiatric patients resettled into the community
}

\author{
Ross Fuhrmann and Clare Reeder
}

\begin{abstract}
If is important to ensure that the financial provision recelved by the long-stay poychiatric population is maintalned as their care is relocated from hospltals to the community. A survey of the provision made by the 20 community homes to which Horton Hospltal patients have been resettled wos conducted. Comparison with the provision recelved by potients prior to reseltiement revealed that the clothing allowance provided for patients without sovings in Horton is often not maintained in the community and that reseltted patients recelve widely difiering and trequently much smaller proviston for clothing.
\end{abstract}

Horton Hospital is a large long-stay psychiatric hospital within the Riverside Mental Health Trust, which is due to close in June 1996, in line with the nationwide move towards closure of the remaining psychiatric hospitals and the "realignment of the resources currently spent on specialist psychiatric services into district based care" (Department of Health, 1991). As these changes occur, it is important to ensure that the broad range of services once provided by psychiatric hospitals are maintained in the community. Since 1985 the Team for the Assessment of Psychiatric Services (TAPS) has been conducting a follow-up study of over 1100 long-term patients discharged from Claybury and Friern hospitals, assessing the success of the transition from hospital to community care. However, one area to receive little attention is the maintenance of the financial provision patients receive when they move into the community. In particular, while hospitals have traditionally taken responsibllity for providing clothing when patients are not able to afford them, community homes are frequently failing to take over this role. Concerns about the regulation of financial provision in community homes are especially acute since the Griffiths (1988) Report precipitated the move towards greater involvement of the independent sector in providing care.

This article attempts to outline current levels of provision in hospitals and community homes, to demonstrate that the provision for people in community care is often insufficient, and to make recommendations to overcome this problem.

\section{Provision for clothing in continuing care}

When a person has been recetving continuing care for more than one year, the social security benefits they have until then been receiving on a weekly basis are automatically down-rated (to $£ 11.75$ in hospital or to $£ 13.35$ in a community home), to take into account the lower cost of living in accommodations where food and other services are provided. This allowance is expected to provide for all the everyday items of personal expenditure not provided by the home or hospital. Until recently it was possible for people in local authority homes to receive grants for clothing in addition to their benefits. However, when in April 1993 their level of personal allowance was increased to be in line with all those supported by public funds, it was decided that "the expectation that the local authority will provide replacement clothing will no longer normally apply" (Local Authority Circular, 1992). The personal allowance is therefore expected to suffice for all people receiving continuing care.

\section{Provision for clothing in Forton Hospital}

If patients at Horton have not managed to save any of their personal allowance the Trust provides $£ 200$ a year for them to spend at the hospital clothes' shop, where clothes are sold at cost price. A $50 \%$ profit margin and $17.5 \%$ VAT is added to clothing to be sold to patients who are able to afford to pay for clothes from savings. If these higher prices are assumed to approximate to the cost of similar items in the high street then the $£ 200$ budget provided for in-patients is equivalent to $£ 352.50$ in the community.

Implicit in this provision is the assumption that patients should not be expected to pay for clothing from their personal allowance. If $£ 300$ 
is taken as a conservative estimate for a yearly clothing budget and subtracted from the annual personal allowance, patients are left with only £7.58 a week to spend on any additional personal expenses. The strain on this budget is increased by two additional difficulties frequently faced by long-stay psychiatric patients. First the welldocumented prevalence of smoking among this population (Hughes et al, 1986) is unlikely to be sustained by a weekly budget of £7.58; second, very few old long-stay patients have retained the budgeting skills required to save for purchases which exceed their weekly income. Even where the weekly allowance is sufficient, they are particularly ill-equipped to prioritise future above immediate requirements.

\section{Survey of provision in community homes}

To assess the extent to which discharged patients experience these difficulties, a survey was conducted of all the community homes to which Horton patients have been resettled since the hospital closure programme began in April 1993. From a total of 20 provisions, including hostels, Part III residential homes and nursing homes. variously owned by health Trusts, local authorities, charities and the private sector, only three homes reported that difficulty funding the purchase of clothing had not arisen. In the remaining 17 homes a wide variety of systems had been established to overcome this difficulty. These systems may be divided into three groups. In three homes a portion of residents' existing income is diverted towards clothing expenses; in two of these homes residents are encouraged to save at least $\$ 2$ a week from their personal allowance, while in the third they receive a loan which they are expected to pay back in small weekly instalments. In ten homes a discretionary supplement is provided in cases where clothes are needed but residents have not managed to save enough. Somewhat unsatisfactory is the diversity of sources from which these supplements are drawn. Four homes drew on an emergency budget set aside by home managers from the fees they recetve from the health authorities. Four homes applied to the local authority for a grant, while the remaining two applied for charitable donations. It should be noted that this system of discretionary supplements is not equivalent to the system operating at Horton. Whereas at Horton patients are given no encouragement to save for clothing, seven out of the ten homes reported that they asked residents to put money aside for this purpose before resorting to alternative sources of funding. Accordingly these alternative budgets are sometimes very small. At one Part III home an
'Emergency residents clothing allowance' of $£ 600$ is expected to provide for 49 residents for a year. Finally, four homes provide an automatic allowance which is drawn from the fees paid by the health authority and is given to all residents in addition to their personal allowance. For example, one hostel provides residents with a quarterly sum of $£ 104$ to be spent on any larger items of expenditure they choose.

The data were analysed to see whether different systems of provision were associated with public, private or voluntary care, or with different levels of dependency. The different systems were fairly evenly spread among private and publicly owned homes, although the sample size may have prevented a pattern emerging. However, three of the four homes which provided automatic allowances to all residents were charity-owned hostels. This may reflect the ethos of the charitable agencies or that automatic allowances are a more appropriate form of provision for the younger, more independent residents of hostels, allowing them to maintain their financial independence and exercise their budgeting skills. Finally, the three homes which reported no difficulty financing the purchase of clothing from the personal allowance or savings were all nursing homes. Staff attributed this to the relatively low expenses incurred by their elderly client group.

\section{Comment}

It is clearly unsatisfactory for the provision of essentials such as clothing to be arranged in such an inconsistent and post hoc manner, and for people of similar needs to receive such widely differing incomes. If this situation is to be improved it is necessary to decide where responsibility for the provision of clothing should lie. The Department of Social Security acknowledges that the benefits it normally provides will on occasion be inadequate, and in limited circumstances is able to provide community care grants, a discretionary 'urgent needs' award drawn from the Social Fund and intended to "promote community care by helping people to move out of, or stay out of, institutional or residential care" (DSS, 1994-95). Provision of clothing is considered suitable for such grants. However, long-stay psychiatric patients are not eligible for these supplements because, although they are leaving institutional care, they are moving into residential homes, which are presumed to provide a similar level of care to that provided by hospitals.

Should it then be the responsibility of the care providers to supply additional clothing? Under this arrangement, community homes would automatically include a clothing allowance in the fees they charge the purchasing authority. This is the system that is in operation in Horton 
Hospital and has been adopted by a number of homes in the community. However, while this remains a traditional rather than legal responsibility, there will always be some homes which prefer to turn to alternative, external sources of funding rather than meet the expense themselves.

The only statutory source of emergency provision for people recelving continuing care appears to be social services grants: "in special circumstances where replacement clothing is required, such as where a resident has unusually high cost clothing requirements because of his or her special needs or because of an emergency such as fire or theft, the local authority can provide clothing" (Local Authority Circular, 1992). However, these conditions are very narrow: as we have seen, lack of finances for clothing is a common rather than an extreme circumstance for discharged psychiatric patients.

\section{Conclusions and recommendations}

Our survey of the difficulties experienced by community homes indicates that the personal allowance is proving an inadequate source of provision for clothing among a significant number of discharged psychiatric patients. It is important that this situation is recognised and the following issues decided:

(1) Who holds responsibility for the provision of clothing to people recetving continuing care when the personal allowance is inadequate?

(2) What mechanism of provision is most suitable? The advantage of a system of discretionary supplements drawn from a central budget is that it takes into account the widely varying needs of residents and avoids the problems caused by poor budgeting skills. The advantage of automatic allowances is that they provide an equal distribution to all residents.

As care for the long-stay psychiatric population is dispersed away from large hospitals and towards smaller community homes in the public. independent and voluntary sectors there is a danger that the broad range of services which hospitals have provided by tradition rather than by obligation may be lost. To prevent this it is essential that the system of community provision is regulated so that homes are clearly accountable to the standards of care which this population needs and has traditionally recetved.

\section{References}

DEPARTMENT OF HEALTH (1991) The Health of the Nation. London: HMSO.

DEPARTMENT OF SOCIAL SECURTY (1995) National Welfare Benefits Handbook 1994-95, 24, 434.

GRIFFTHS. R. (1988) Community Care: Agenda for Action. A Report to the Secretary of State for Soctal Services by Str Roy Griffiths. London: HMSO.

Hughes, J. R., HATSUKAMa, D. K., MrTCHEL, J. E., et al (1986) Prevalence of smokdng among psychiatric patients. American Journal of Psychiatry. 143, 993-997.

LOCAL AUTHORTY CIRCULAR (1992) Vol. 19, paragraph 8. London: HMSO.

*Ross Fuhrmann, Assistant Psychologist, and Clare Reeder, Assistant Psychologist, Horton Hospital, Long Grove Road, Epsom, Surrey KT19 $8 P Z$

*Correspondence 